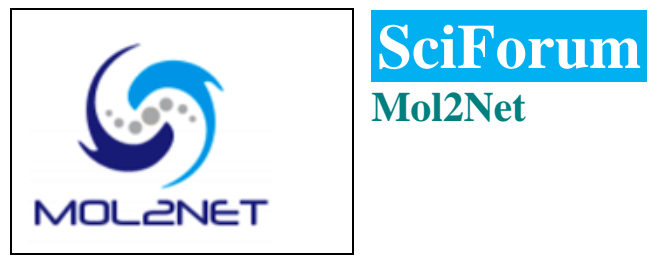

\title{
Prediction of the Antagonistic Activity On the Receiving AT1 of the Angiotensin II
}

MSc. Luis Alberto Torres Gómez ${ }^{1}$, Lic Laura Machin Galarza ${ }^{1}$, Seangkin Bun ${ }^{2}$

1 Department of Pharmacy. Institute of Pharmacy and Foods. University of the Havana

2. International university of health sciences in Cambodia

luistg@ifal.uh.cu tel. 53-7-2051292

laura@ifal.uh.cu

seangkhinbun@gmail.com

Received: / Accepted: / Published:

The prediction of the antagonistic activity on the receivers of the Angiotensin II (AII) for diverse compounds, using molecular describers of topologic order calculated with the software DRAGON, allowed generate 81 independent variables. A total of 202 compounds divided in two series was used: one of training that included 176 compounds, with 41 compounds in the active group and 135 in the inactive one; and a second serie of prediction, integrated by 26 compounds, of which 7 are considered active and 19 take part in the inactive one. After the carry out of the model's validation, were achieved a $97.73 \%$ of good classification for the training serie and a $96.15 \%$ of good total classification for the prediction one. The later evaluation in the developed pattern of structures with new molecular entities, that were obtained by molecular modification, showed that 4 of them could be potentially active. The results demonstrated that the factor to modify is the alone since lipophilic property is allowed practically to subtract carbons in the chain carbon atoms and to maintain the activity, not happening this if they modify the heterocyclic systems, what seems to indicate that the same ones are part of the pharmacophore. Comparison settled down with other reported models, using different calculation ways, demonstrated the superiority of the methodology developed in our work. For the development of new drugs, the discovery of new series heads to considered like possible active agents that blockade the receiving AT1 of the angiotensin II is a promissory alternative that opens up to the generation of new libraries of compounds that facilitate the virtual sifted.

Keywords: QSAR, drugs design, angiotensin, antagonistic 


\section{Introduction}

The development of new active components represents an expensive process for the pharmaceutical industry, stimulating in the last few years the rational design using differents methodologies. The relation between the drug's molecular structure and its pharmacological properties supports some of these news methods, that use molecular describers of topologic order to achieve acceptable aproximations.

The calculation of them is based on the concepts of the grapho-theory applied to the Organic Chemistry.

The molecular describers were employed in our work as useful predictors of the AT1 receptors's antagonistic activity from the Angiotensin II, as well as for the chemical and physics interpretation of the enlace's contribution to this effect.

\section{Results and Discussion}

After the definition of the prediction serie, the Cluster K-means test was carried on, grouping in 7 cluster and taking into account the structural variability of the inactive data.

The initial analysis mainly grouped the active data in one cluster, indicating a regular behavior in their structures. This result showed that the data was homogeneous, being significant the fact that only two compounds appertaining to the active serie were found at a cluster with inactive compounds; meanwhile in the active compounds's cluster two members from the inactive serie appeared.

The model obtained using the results of the Cluster test allowed a good classification for the actives and inactives of $92.68 \%$ and $99.26 \%$ respectively, as well as an adequate total classification of $97.73 \%$. Later on the variables in the model used (Table 1), wherein $\lambda$ is Wilks's lambda, D2 is Mahalanobis's distance and F, the Fisher's parameter.

Tabla 1. Variables incluidas en el modelo

\begin{tabular}{|c|c|c|}
\hline Variables & G_1:1 $\mathrm{p}=.23762$ & $\mathrm{G} \_2:-1 \mathrm{p}=.76238$ \\
\hline SIC0 & -7088.72 & -7852.53 \\
\hline CIC0 & -1300.63 & -1448.29 \\
\hline IC2 & 5157.89 & 5358.63 \\
\hline CIC2 & 5083.87 & 5276.74 \\
\hline IC3 & -4977.50 & -5101.81 \\
\hline SIC3 & 25379.14 & 25972.88 \\
\hline Constante & -9631.03 & -9842.26 \\
\hline
\end{tabular}

\section{Materials and Methods}

A training serie of 202 active and inactive compounds was designed. The spectral moments of each compound was obtained taking into account the molecular graphos with the dipolo moment and the distance of enlace; leading to the obtention of a matrix with the spectral moments from 0 to 15 for each compound.

The spectral moments used were calculated with the Modeslab program. The processing of the data to create new variables was carried out with the electronic tabulator Microsoft Excel version 10.0 for Windows. Later on, the Excel's lists were processed with the software STATISTICA version 8.5 for Windows, using the lineal discriminant assay for the obtention of the classification models.

\section{Conclusions}

New possible drugs that blockade the AT1 receptors of Angiotensin II are feasible with the results of the present work. The Cluster analysis demonstrated the structural regularity in the active data, as well as the heterogeneity in the inactive one; thanks to the training and prediction series's that allowed the obtention of a model capable to predict the antagonistic activity of AT1 receptors.

\section{References and Notes}

1. Molecules containing heteroatoms and QSAR applications. Journal. Chem. Inf. Comput. Sci, 1997. 4(37): p. 320-328.

2. Florez, J., Farmacología Humana. 2002, Madrid: Masson S.A.

3. González, V., L. Fernández, and A. Ruibal, Antagonistas de los receptores de la angiotensinaII: revisión de estudios multicéntricos. Revista Cubana de Medicina Intensiva y Emergencias, 2005. 4.

4. J., T. and R. Caballero, Los antagonistas de los receptores de la Angiotensina II han cumplido las expectativas. Monocardio, 31. Juan Tamargo, Ricardo Caballero. 4.

5. López-Farré, A. and J. Guerra, Otros efectos de los antagonistas de los receptores

AT1 de angiotensina II. Laboratorio de Investigación Cardiovascular e Hipertensión, 2004. 2(10): p. 108-113.

6. Publica, E.A.d.S., Antihipertensivos antagonistas de los receptores de la angiotensina II: puesta al dia. Boletin terapeutico Andaluz, 2000. 16(1). 
7. Tamargo, J., et al., Los antagonistas de los receptores de la angiotensina II han cumplido las expectativas. Monocardio, 2002. 4.

8. . Kubinyi, H., In Hansch, C., Sammes, P. G., Taylor, J.B. and Ramdsen, C.A. , Quantitative Drug Design, Pergamon. Medicinal Chemistry, 1990. 4(5): p. 589-643.

9. Gago, F., Métodos computacionales de modelo molecular y diseño de fármacos. 2000, España: Farmaindustria. 254-256.

10. Font, A. and V. Monte, Métodos variacionales. 1994, España: Farmaindustria.

11. Gao, H., Application of BCUT metrics and genetic algorithm in binary $Q S A R$ 